Gertrude Mudge, 1886-1958

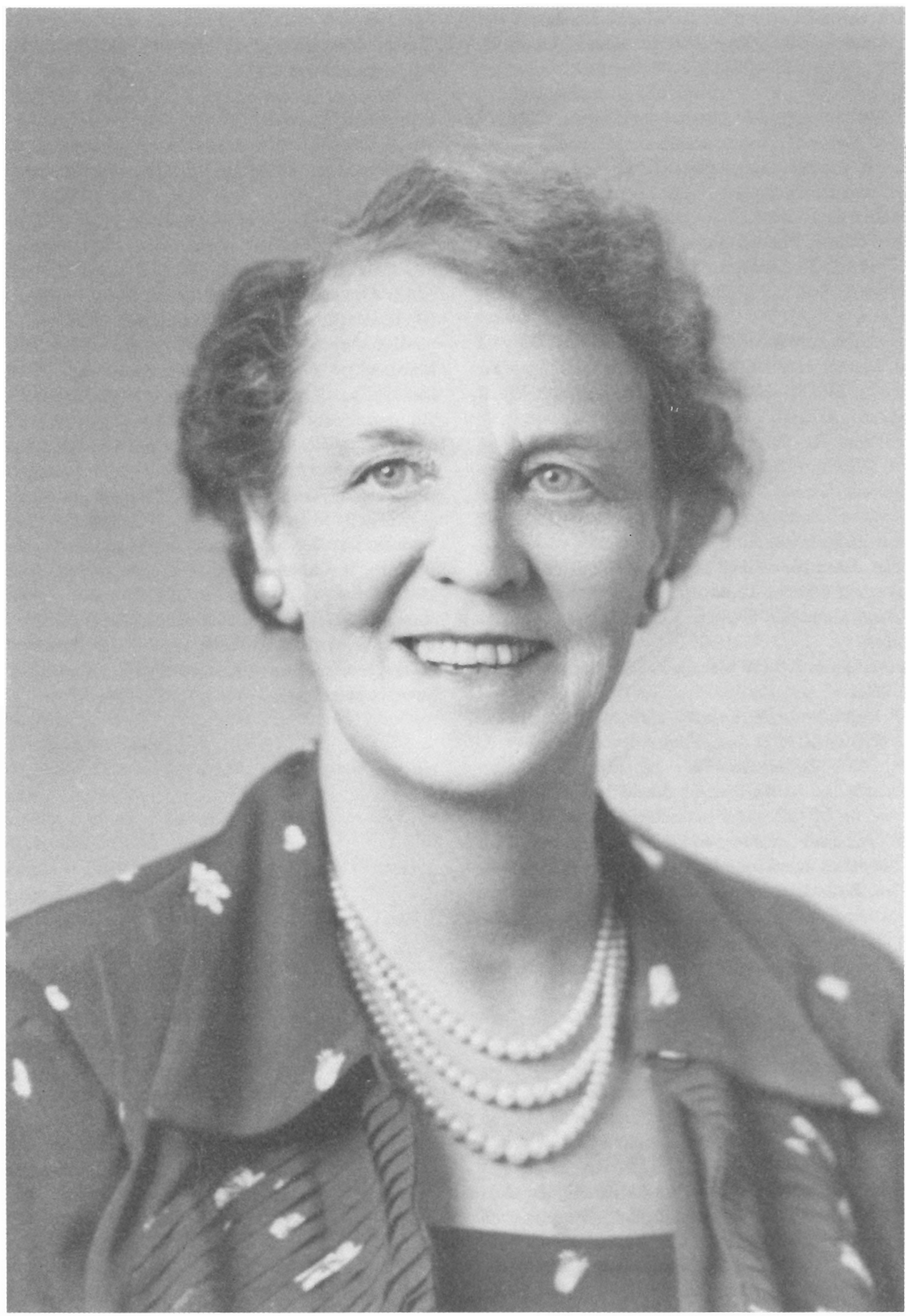




\section{"That Best Portion of a Good Woman's Life": Gertrude Mudge, 1886-1958}

\section{by Peter Hanlon}

While the prestige of McGill rests primarily upon the high caliber of its academic staff, McGill's good name and fame also derive from the dedication and integrity of its administrative and technical officers who have helped to give the university "cohesiveness and unity of purpose." The story of these dedicated men and women remains largely untold but it is an important part of the history of McGill. One such person was Miss Gertrude Mudge who, from 1923 to 1953, served as the virtually indispensable right-hand of the Faculty of Medicine. Miss Mudge's discernment and understanding determined the essential character of her office as a vital, positive and motivating force in the lives of the medical students. Her generous spirit and quiet influence were famous through two generations of aspiring physicians. Following her retirement, Miss Mudge set out on a long pilgrimage across the United States and Canada to visit her scattered medical family. Her sentimental journey received wide publicity, and the renown of McGill grew as a result. In 1955, McGill awarded Miss Mudge an honorary Master of Arts in recognition of her years of devoted service which helped to sustain the university's pre-eminent position in medical education.

Même si le prestige de McGill repose essentiellement sur le très haut calibre de son personnel enseignant, l'Université tire également une bonne part de sa réputation et de sa célébrité du dévouement et de l'intégrité des membres de son personnel administratif et technique qui ont contribué à lui donner "cohésion et unité». Quoiqu'elle fasse partie intégrante de l'histoire de l'Université, la vie de ces hommes et de ces femmes est très souvent passée sous silence. Celle de Miss Gertrude Mudge qui, de 1923 à 1953, a été le bras droit quasi indipensable de la faculté de médecine fera toutefois exception à cette règle. Par son discernement et sa compréhension, Miss Mudge a joué un rôle vital, positif et motivant dans la vie des étudiants de médecine. Sa générosité et son influence tranquille ont marqué deux générations d'aspirants médecins. Suite à sa retraite, Miss Mudge a entrepris un long pélerinage à travers les États-Unis et le Canada pour rendre visite à tous les anciens étudiants de médecine qu'elle avait connus. Ce voyage sentimental a bénéficié d'une grande publicité, ce qui a contribué à accroître la renommée de McGill. En 1955, McGill lui a attribué une maîtrise ès arts honoris causa en hommage à ce dévouement largement responsable de la prééminence de la faculté de médecine de l'Université McGill.

For wisdom is better than rubies;

and all the things that may be desired

are not to be compared to it.

Proverbs, 8:11

The highest form of wisdom is kindness.

Talmud: Berakoth, 17a

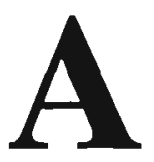
kind heart is a fountain of sunshine which raises the spirits and binds the human family together. Such was the person of Miss Gertrude Dupuy Mudge whose life was marked by faithful toil and a keen sense of the golden rule. Loved and esteemed by all who knew her at McGill University, Miss Mudge brought her special gift of service to the Faculty of Medicine where from 1923 to 1953 , as the Assistant Secretary, she discharged her responsibilities with a gladness of spirit born of quiet self-possession. But it was ber ability to enter sympathetically into the experiences of the medical students that earned her a niche in the pantheon of McGill notables who have brought distinction to the University. Revered for her kindly, sympathetic deeds and the wisdom of her counsels, she let charity measure all her actions. Miss Mudge's life is worthy of examination because there were, and are, other Mudges 
at McGill and other institutions of bigher education who "in the comparative obscurity of administrative departments... help to give a university... cohesiveness and unity of purpose. ${ }^{11}$ By overlooking these "lesser lights, "2 we miss opportunities for broadening our understanding of the formation of character and acquiring new insights into how everyday social contexts shape and direct moral selfhood and right action.

Born into a moderately prosperous middle class family, Miss Mudge was the youngest of five surviving children. Her birth on 13 September 1886 came at a distressful time in the family's fortunes for only a month or so earlier, creditors had forced her father into bankruptcy with the resultant loss of his founders' supplies business. ${ }^{3}$ At 52 years of age when most men are securely ensconced in comfortable circumstances, Nicholas Richard Mudge found bimself facing an uncertain future. But Nicholas was not one to let adversity pull him down. Soon he was back in business as an insurance broker and eventually became manager of the Montreal branch of the Boiler Inspection and Insurance Company of Canada. As a prominent lay leader in St. George's Anglican Church, his connections there may have helped him get back on his feet.

Sometime during this transition, Nicholas moved his family from their comfortable greystone row house on Coursol Street to an attractive 12-room single family dwelling on Lorne Avenue near McGill University. The spacious, tree-lined grounds of the McGill Campus were a favorite spot for the unrestricted activity - when they could get away with it $\longrightarrow$ of the neighborhood children. As a young girl, Miss Mudge tried to play on the grounds "only to be chased out," as she recalled, "by 'Jimney the Spider,' Tom Graydon's assistant, for in those days only Professors' children were allowed to play on the Campus." 4

When she was 6 years old, her mother died of pneumonia and her oldest sister, Isobel, and her aunt, Laura Mudge, who had been living with the family since at least $1891,{ }^{5}$ assumed the management of the household and helped her over this difficult emotional crisis. It would not be the first time that Miss Mudge understood death. In 1906, her sister, Helen, died of chronic endocarditis at 29 years of age. ${ }^{6}$ Two years earlier her father had suffered a severe stroke from which he never recovered. ${ }^{7}$ For the next six years she continued at home to help her two remaining sisters, Isobel and Maude, and her aunt care for him while her brother carried on at the Boiler Inspection and Insurance Company.

The death of her father in March $1910^{8}$ finally freed her for a life of her own. She was never really interested in marriage for she apparently saw no way of reconciling personal growth within the bounds of matrimony. While she appreciated the claims of family, she preferred the path of individual self-development within the context of a career. Her courageous decision, however, carried a penalty, for a working woman of breeding was deemed unworthy of her station, and some of Miss Mudge's friends snubbed her. It was a bitter experience. ${ }^{9}$

When Miss Mudge stepped out on her own, she carried with her an unswerving commitment to the idea of service which was a characteristic of the Mudge women. Her sister, Maude, for example, was closely associated with the activities of the Anglican Diocese of Montreal and was for a number of years secretary to Bishop John Cragg Farthing. ${ }^{10} \mathrm{Her}$ aunt, Laura, was "the leading figure" in the Girls' Friendly Society from its inception in the Diocese in 1885. "And her cousin, Nora, was Secretary-Treasurer of the St. George's Women's Auxiliary and a member of the Dorcas Society. ${ }^{12}$ Although Miss Mudge was never connected with these types of endeavour, the same sense of responsibility and duty was an energizing factor in the realization of her own womanhood.

Miss Mudge's first position was as a secretary for Atkinson, Glassco and Lawrence, consulting engineers, where Archibald Patrick Stinson Glassco, later Bursar at McGill, was the chief engineer. Subsequently, she found employment with the law firm of Thomas Shearer Stewart and his younger brother, William. One of her tasks at Stewart and Stewart was the typing and filing of the correspondence and other papers of the Graduates' Society of McGill of which William was the secretary. ${ }^{13}$

In one way or another, McGill had always been a part of Miss Mudge's life and so on 1 May 1915 when she joined the university as a clerk in the Registrar's Office, the progression seemed perfectly natural. A 
conscientious worker, her earnest attention to all aspects of her job and her kindly disposition soon got her promoted to the Assistant to the Registrar. When the Dean of Medicine, Dr. Charles Ferdinand Martin, sought to fill the position of Assistant Secretary of the Faculty, left vacant in 1923 by the tragic lcss to cancer of Miss Mary Eadie Brand, he looked no further than the central office where Miss Mudge's worth was warrant for her welcome. ${ }^{14}$ And so her long and distinguished career with the Faculty of Medicine began when Principal Sir Arthur Currie informed her that the Dean had requested that she be transferred to that Faculty. "I was not anxious to make the change," she recalled, "but who could say 'no' to Sir Arthur?"15 Thus began an association with the University's senior faculty that was to mark the happiest years of her life.

At the time of Miss Mudge's transfer, the medical office consisted of the Dean, Dr. Martin, and the Secretary, Dr. James Crawford Simpson. Both men had only recently been appointed to their respective positions. Dr. Martin was McGill's first full-time Dean of Medicine and charged with the responsibility of reorganizing and expanding the faculty. To help ease the burden of deanship, Dr. Simpson devoted most of his time to the secretarial work of the faculty. But the heart and pulse of the administration was Miss Mudge. While matters of policy were always the responsibility of the Dean, the day to day decisions which allow things to get done was the area where she played such an important role in enabling the Secretary to get on with his work.

In mind and character, Miss Mudge was a worthy partner of this triumvirate, and Dr. Simpson, as did his successors, relied on her to manage the office and to furnish administrative services. ${ }^{16}$ His opening remark to her was, "I'm a terrible procrastinator and you'll have to keep after me," which she did for over seventeen years. ${ }^{17}$ The immediate task which confronted them was the reorganization of the entire filing and record keeping system. This challenging assignment required many long hours back at the office in the evenings. If the work was arduous, it was also satisfying. "With such a kindly and understanding man," recalled Miss Mudge, "we were always able to find a solution for even the most abstruse problem and he was almost too ready to take the blame for any mistakes, whether his or mine. I can still hear him say, 'We must have a policy,' emphasizing his remark by an energetic right forefinger on his left palm. "18 The reorganization was so successful that it was recognized by the American Medical Association as a model of efficiency.

When Dr. Simpson died on 20 April 1944 (only three years into his retirement), Miss Mudge was asked if she would write an appreciation of his life and work. At first she did not feel equal to the task but with Dr. Martin's encouragement, she decided to try. The result was an exceptionally fine tribute that could only have been written by one who knew and shared his work. She wrote with great sensitivity and perception, exquisitely capturing the essential spirit of this remarkably gentle man who was an inspiration not only to his students but to his colleagues. She received many congratulatory letters for writing about him as she did, but the finest compliment came from Dr. Simpson's staunch friend and admirer, Professor Roy Fraser of the Department of Biology and Bacteriology at Mount Allison University:

You wrote of Dr. Simpson as it should be
done, and all who held him in affection and
respect (and who did not?) will be very
greatly in your debt. No one could have
done it so well, for you knew his work and
his gentle, sunny, friendly, helpful nature
better than any one. I valued his friendship,
and although men are mostly very shy about
speaking their feelings to each other, he
knew the measure of my admiration. Only
those of us (and you are of that number)
who know and love science and medicine
can really understand the intense admiration
that is always felt for fine teaching by those
who profit by it, either as students or as
colleagues. By all the gods, J.C. could
teach! ${ }^{9}$

Miss Mudge replied that some people thought her article was too personal, but "how could I write otherwise," she said, "about one who had meant so much to me. You can get statistics out of Who's Who. "20 Dr. William Willoughby Francis, curator of the Osler Library, summed it up with this comment: "Leacock says that the best writing is done with the pen-he's wrong, the best is done with the heart. ${ }^{121}$ 
In the death of Dr. Simpson, Miss Mudge lost not simply a "considerate" team mate but a "wonderful friend." What she cherished in their relationship, in addition to his kindliness, was his high regard for her capabilities and his readiness to combine his special talents with hers in the pursuit of common objectives. Her affection for him, one suspects, bordered on love but her strong sense of the proprieties never allowed her even so much as to intimate such feelings. When Dr. Simpson died, a part of Miss Mudge died, too, ${ }^{22}$ and the shock of his passing cast a pall of weariness over her which intensified her uneasy awareness of the many changes she had lived through at McGill. The distress and suffering caused by her chronic rheumatism and the interminable brutality of the Second World War only heightened her sense of the brevity of life. ${ }^{23}$ But her well disciplined temperament dismissed these morbid thoughts in dutiful regard to her vocation.

Guided solely by her devotion to the school, she "constantly added to her tasks over the years. "24 These included responsibilities as diverse as registration, drafting examination timetables, maintenance of student records, printing the examinations and compiling the results, ensuring that hospitals had completed the intern report forms and entering their comments on the student record cards, making arrangements for the Way of Life Ceremony, ensuring that prizes were ready for presentation, keeping the notice boards up-to-date, and performing various clerical functions for the McGill chapter of the Alpha Omega Alpha Society. In addition to her ramified and broad administrative responsibilities, Miss Mudge was the information hub of the faculty. In the course of a typical working day, she answered countless telephone enquiries from various university departments, the hospitals, the students and the public. As well, she attended to a seemingly endless string of enquiries over the counter which usually began first thing in the morning. ${ }^{25}$ Despite the constant interruptions, Miss Mudge's patience and systematic work habits allowed her to accomplish her multifarious responsibilities with facility.

When Dr. Martin offered Miss Mudge the job of Assistant Secretary, she asked him what her duties would be. His reply clearly indicated that mothering skills would be an integral part of the job and vital to her success. "Your principal duty is to be a friend to the students. If they want to cry on your shoulder, you'll be there; and if they're happy and want to laugh, then you can laugh with them.'"26 The maternal role suited her perfectly, and her sympathetic personality soon transformed the office into a center of domesticity as she demonstrated a "surprisingly rapid understanding of the needs of the average medical student. 127 Thereafter, Dr. Martin referred to Miss Mudge as "our Secretary in charge of students. 128

A valued friend and confidante to two generations of medical students, Miss Mudge maintained an open door policy for their benefit. She acted as the faculty spokesperson on many matters directly affecting the students and dealt promptly with all their questions. As a result, it was seldom necessary for them to see the Dean or the Secretary. Keenly aware of how precious time was to these hopeful young men and women, Miss Mudge made it a point of pride that they were never turned away empty-handed or told to come back later. ${ }^{29}$ Her ready smile and obliging manner gave encouragement to those who sought her advice and counsel. She instinctively knew the right thing to say and "always seemed to be able to build their confidence with ... a ray of sunshine. ${ }^{130}$ But when the occasion demanded, observed Dr. Martin, Miss Mudge could "dress them down in a way nobody else could."31 Reginald E.L. Watson (Med. '34) recalls that "she encouraged, advised and reprimanded us all as she saw fit, and her opinions ... carried great weight ... and were highly valued." 132 She expected these aspiring physicians to conduct themselves in a manner befitting the dignity of their chosen profession and to apply themselves diligently to their studies. "My very first recollection of Gertrude Mudge," reminisced Mark R. Marshall (Med. '26), "is the occasion when she suggested in the kindliest of tones, to one of my classmates that perhaps it would be to his advantage to devote more time to his studies and less to dances and other social activities: an unexpected comment, but with most beneficial effects. ${ }^{133}$ An accurate observer of people and a shrewd judge of character, she knew a great deal about the personal lives and affairs of the students, and both the Dean and the Secretary made good use of her knowledge when scholarships and jobs were being considered. ${ }^{34}$ Their trust in her qualities of reason and calm judgment was implicit. 
Women were fairly recent arrivals to the medical student body when she joined the faculty. Some of the professors took a dim view of women in medicine, but Miss Mudge did not accept the division of the world into male and female spheres. She admired the pluck and determination of these young women who sought to fashion their own lives in the face of ancient prejudice and soon became their "staunch friend and champion. "135 Evidence of female inequality and male resistance to medical co-education was the lack of suitable toilet arrangements for women in the Medical Building. Miss Mudge quietly took them under her wing and successfully pleaded their cause for better facilities. She also assisted them in finding suitable lodgings for as semi-graduate students, they were ineligible to apply for accommodations in Royal Victoria College. ${ }^{36}$

Aside from the McGill Women's Medical Society, there were no associations open to women in medicine which aimed simply at good fellowship. They were expected to organize their own social activities, and Miss Mudge did much to encourage them in this way. Occasionally she would entertain them herself on weekends. She was always a great favorite with the women students who affectionately called her "Mudgy" and automatically included her in their official activities. Honor M. Kidd (Med. '47) writes:

Before my time as President of the Medical Women's Undergraduate Society, the annual dinner was a rather dull affair, with a serious after dinner speaker, and poorly attended. We livened things up by substituting a quiz programme for the speaker. The prizes were a weird and wonderful assortment, but our best was a rather moth-eaten moose's head of such an enormous size that it was quite a problem getting it into the Windsor Hotel where the dinner was held. Since you can only have fun with your friends, we decided that come what may Mudgy was going to win the moose's head. Her quiz question was "How do you make a chocolate moose?" If she knew, she got the moose, if she didn't know, she still got the moose as a booby prize! Have forgotten now whether she knew or not, but she flatly refused to accept her trophy, even though we assured her that its moth-eaten character would never show if it were hung high in the halls of the medical building. This evening is one of my happiest memories of Mudgy-she thoroughly enjoyed our fun, and thought it was a huge joke that the dinner organizers were left to dispose of her ungainly prize! ${ }^{37}$

Clearly Miss Mudge owed much of her success to a genuine sense of humour which revealed itself in her alertness and breadth of mind, in her keen sense of proportion, in her faculty of quick observation and in the charity of her judgements. She delighted in the company of others and appreciated the whimsicalities and contradictions of life.

Not only was she a staunch friend of women in medicine, she was also a staunch friend of the wives of men in medicine. According to one of the wives, Miss Mudge started a "Wives' Club" which met periodically for conviviality.

Each term, the presiding club president
would appear at Miss Mudge's office for
the new list of 'marrieds,' and from then
on, it was all 'fun.' She ... got us
invitations to things ... given by Lady this
or that, in a lovely home, or memberships
in groups such as the Needlework Guild of
Canada. Dr. Lyman Duff, at that time a
Professor of Pathology, perhaps at her
instigation entertained us beautifully one
Sunday lunch.

The club provided these lonely young wives, whose husbands were "too preoccupied with studies to have much time for entertainment, " ${ }^{39}$ with much needed companionship and an opportunity to let their hair down.

The outstanding quality of her character was kindness. Interestingly the word 'kindness' originally meant 'kinship' and the warm feelings associated with family ties. The Faculty of Medicine was like home to Miss Mudge, and she looked upon the students with the same affection and sense of responsibility which find natural expression in the bond between parent and child. They were her "boys" and "girls." Her warmbearted readiness to assist needy students was well known and in one instance, she acted as surety for a 
student by putting some securities in pledge against a loan he had received from a bank..$^{40}$ Miss Mudge's "musical Sunday nights" were a refreshing uplift after a long, hard week of study. Before she moved into Lehman's guest house on Mountain Street, she would invite several of the students and their wives over to her suite in the Somerset Apartments on Sherbrooke Street each Sunday for dinner and an evening of music. Sometimes the students would bring their own instruments. And every Christmas she saw to it that those out-of-town students who were unable to get home for the holidays enjoyed a home-cooked turkey dinner with her. ${ }^{41}$

As her "boys" and "girls" graduated and scattered around the world, she never lost touch with them. Every Christmas she exchanged hundreds of cards and greetings with her "students." 42 She was also a familiar figure at class reunions, and it was her presence that made these gathering such memorable occasions. The former registrar, Thomas Henry Matthews, noted that "those who have wondered why medical reunions are so successful might discover, by tactful questions, that the doctors really come back to Montreal to see Miss Mudge. They appreciate her qualities and she appreciates theirs. "43 At the celebrations marking the 25 th anniversary of the class of 1924, one physician remembered the "thrill " of being "recognized at once" by Miss Mudge after the lapse of so many years. ${ }^{44}$ Clearly her remarkable memory for names was an extension of her native kindliness and her genuine interest in people.

When she retired at the end of 1953, Miss Mudge had served McGill for thirty-eight years with untiring and selfless devotion, and for thirty years had gently and sometimes firmly guided the fortunes of over 3,000 medical undergraduates. During that year, she was the recipient of many honours. In March she was the guest of honour at the annual Medical Ball-the first person ever to be accorded such recognition-with the largest attendance ever. During the supper hour, James $H$. Duxbury (Med. '53) presented her with a combination radio and phonograph on behalf of the Undergraduate Medical Society. ${ }^{45}$ She was also made Permanent Honorary Editor of the McGill Medical Journal. ${ }^{46}$ In June a committee was formed to solicit contributions to The Gertrude Mudge Fund. ${ }^{47}$ The response was immediate. McGill medical graduates from many parts of the world tangibly expressed their great affection for her in the form of a 'purse' which amounted to over $\$ 5,000$. They felt privileged and honoured to be asked to pay this small tribute to one to whom they owed so much. There was not one contribution that was not accompanied by at least a short note of appreciation recalling her friendly interest and ready helpfulness.

The committee set a limit of $\$ 5.00$ per person, but some donated more than this. One physician, construing this limit to mean the lower limit, gave $\$ 50.00$ with the explanation: "It's the least I can do for someone who has done so much for McGill medical students. "48 Another, in contributing $\$ 25.00$, reasoned, "It is ... more than you asked for, but some cannot send any because of recent graduation and others may not send any and the addition is sent so Miss Mudge's fund will be somewhat nearer the figure that you had hoped to get for her." 49 Richard Jamieson (Med. '42) probably expressed the sentiments of all when he wrote, "I know of no other fund-large or small-to which I have contributed that gives me such great personal pleasure as this. " ${ }^{10}$ The presentation took place in December and consisted of a suitably engraved sterling silver quaich bowl and a handsome check which she later used to finance a long-planned sentimental journey across the United States and Canada to honour a promise in answer to repeated invitations from "her former students" that she would visit them on her retirement. ${ }^{51}$

In early March 1954, at 68 years of age, Miss Mudge departed Montreal in her Plymouth sedan to see her medical family. Armed with the names of more than one thousand doctors, she spent the next eight months on the road renewing old friendships. She never stayed more than a few days in any place. There were so many people to visit, and as she said, "I've got to get around and see how the rest of my boys are." ${ }^{52}$ Wherever she went, McGill doctors plied her with questions, particularly about former professors. "They were grateful," she said, "for what they considered the more individual method of instruction based on the bedside method of teaching made famous by Sir William Osler. " ${ }^{53}$ It gave her tremendous satisfaction to see these men, whom she had guided through their years at medical school, now with families of their own, so successfully established in their respective communities. Miss Mudge's extensive tour was more than just a promise kept; it was also an unofficial 
goodwill mission for the university and as such received wide publicity through the offices of the Graduates' Society of McGill and many of its branches. ${ }^{54}$ Dean Donald H. Fleming noted that her tour "served to strengthen the links binding our graduates in Medicine to the University. "ss

We do not know if Miss Mudge got to visit any of her "girls." There were very few of them anyway. Of the 3,072 medical students who graduated during her 30 years with the faculty, only 139 or 4.5 per cent were women. ${ }^{56}$ In an interview with a reporter from The Vancouver Sun, she noted that women were still not fully welcomed into medicine at McGill. "Of the 116 potential doctors who will be admitted this Fall," she observed, "only eight will be women. And approximately 180 will seek admission, " she added with telling effect. ${ }^{57}$ The explanation, said Miss Mudge, lay in the age old problem of trying to combine marriage and a medical career.

It is not that women make poor doctors. On the contrary, they usually do extremely well. But women so often get married during their training, or, after it, have babies, that we keep our women students down. ${ }^{58}$

It was a matter of regret with Miss Mudge that men were perceived as taking medicine more seriously than women. ${ }^{59}$

When Miss Mudge opened her mail on Friday, 25 February 1955, she was "astounded" to find a letter from Principal F. Cyril James inviting her to the Spring Convocation in order that Chancellor Bertie Charles Gardner might confer on her the degree of Master of Arts, honoris causa. ${ }^{\infty}$ The honour capped an outstanding career of a remarkable women whose "faithful and efficient service" as Assistant Secretary of the Faculty of Medicine was distinguished by the "warm human qualities" which she brought to that position. ${ }^{61}$ Dr. Harold Willis Dodds, President of Princeton University, who delivered the convocation address, could have had Miss Mudge in mind when he stressed the absolute importance of wisdom in the "complex interrelations of life. "62
On 21 January 1958, Miss Mudge died in her 72nd year at the Royal Victoria Hospital. ${ }^{63}$ That same year the Gertrude Mudge Memorial Student Aid Fund was begun to help medical undergraduates in need of financial assistance, thus continuing a thing which she did unofficially during her lifetime. ${ }^{64}$ The story is told by her personal physician and former lecturer in the Faculty of Medicine, Walter de Mouilpied Scriver, of an incident which took place in her office prior to her retirement. Noting a memorial plaque which had been erected to her predecessor, Miss Brand, ${ }^{65}$ he jestingly remarked that a larger one would be required to fit her qualities. "If anybody puts up a plaque for me," Miss Mudge quickly replied, "I'll come and haunt them." Dr. Scriver commented that the committee "used this [remark] with good effect in launching our campaign for funds. ${ }^{166}$

Miss Mudge's death was the occasion of an exceptionally fine editorial in The Montreal Star in tribute to her "grand qualities of heart and mind, 167 an honour accorded only to those rare persons of uncommon character.

There is mourning today that spreads far beyond the halls of the faculty of medicine at McGill University. Miss Mudge's "boys" are grieving. Even though they are doctors and so more insulated against the shock of death, the passing of Miss Gertrude D. Mudge carries a greater sting. For her boys - and girls, too-will reflect on Miss Mudge not so much from their contacts of maturer years, but from their deeper memories of her in their student days. ${ }^{68}$

In the gladness of remembrance, her reassuring presence lives again. "My student days at McGill were the happiest of my life," recalls one graduate. "This was due, in no small part, to association with such wonderful persons as Miss Mudge. Thoughts of the Faculty of Medicine are thoughts of her. ${ }^{69}$

\section{Notes}

The title "That Best Portion of a Good Woman's Life" was adapted from Wordsworth's Lines Composed a Few Miles above Tintern Abbey. 
The documents referred to below originally belonged to the author who donated them to the McGill University Archives in May 1994:

GDM Gertrude D. Mudge Papers, M.G. 4180, McGill University Archives.

MUA McGill University Archives

1. "McGill Convocation" (Editorial), The Montreal Star, 25 May 1955, p. 10.

2. T.H. Matthews, "Stars of the Second Magnitude-but Stars," The McGill News, 31 (Summer 1950): 28.

3. Gazette officielle de Québec, 1886, pp. 1703, 1786; "By the Way," The Gazette (Montreal), 16 Aug 1886, p. 3; "City and District News," The Gazette (Montreal), 18 Aug 1886, p. 3; The Montreal Daily Star, 6 Sep 1886, p. [2].

4. GDM, M.G. 4180, file 7, autobiographical notes intended for a speech in reply to receiving her honorary degree [never read].

5. 1891 Federal census, MF reel T-6407, Montreal, St. Antoine Ward, Division 29, p. 16, U. 20-25 and p. 17 U. 13.

6. Mount Royal Cemetery, Montreal, files.

7. The Boiler Inspection and Insurance Company of Canada, Toronto, ON, Harold Mudge, "Montreal Story: Backgrounder no. 13" in Background to Centennial, bi\&i, 1875-1975.

8. "Mr. Nicholas Mudge Has Passed Away," The Montreal Daily Herald, 23 Mar 1910, p. 2.

9. As told to the author by his mother.

10. "Miss Maud [sic] Mudge Borne to Grave: Private Secretary of Bishop Farthing Mourned by Many Friends," The Gazette (Montreal), 21 Mar 1929, p. 11.

11. John Irwin Cooper, The Blessed Communion: The Origins and History of the Diocese of Montreal, 1760-1960, [Montreal] The Archives Committee of the Diocese of Montreal, 1960), p. 127.

12. St. George's Anglican Church, Montreal, Women's Auxiliary, Minute Book, 10 Nov 1913 - 28 Apr 1930.

13. GDM, M.G. 4180, file 7, autobiographical notes intended for a speech in reply to receiving her honourary degree [never read].

14. Osler Library, MS 277, Shelf 1, C.F. Martin, "Dinner [speech] for Dr. J.C. Simpson - 3rd June, 1941," p. 4.

15. Gertrude Mudge, "J.C. Simpson," The McGill News, 25 (Summer 1944): 18.

16. GDM, M.G. 4180, file 5, Ethel Simpson to Gertrude Mudge, 27 May [1944].

17. Gertrude Mudge, "J.C. Simpson," The McGill News, 25 (Summer 1944): 18.

18. Ibid.

19. GDM, M.G. 4180, file 5, Roy Fraser to Gertrude Mudge, 21 Jul 1944.

20. Ibid., Gertrude Mudge to Roy Fraser, 24 July 1944.
21. Ibid., Gertrude Mudge to Teck [Harold Cedrick] Alward, 13 Jun 1944.

22. As told to the author by his mother.

23. GDM, M.G. 4180, file 5, passim.

24. Donald H. Fleming, "In memoriam: Miss Gertrude D. Mudge," McGill Medical Journal, 27 (Feb 1958): 1. This memorial is recorded in the Minutes of the Faculty of Medicine.

25. GDM, M.G. 4180, file 3, passim. MUA, RG 38, Container 5, file 117, Howard L. Elliot to Gertrude Mudge, 10 Oct 1928; Gertrude Mudge to Howard L. Elliot, 11 Oct 1928; Circular letter signed by Howard L. Elliot, $10 \mathrm{Dec}$ 1928.

26. Mary McAlpine, "Cupid Hinders Women Doctors," The Vancouver Sun, 18 Aug 1954, p. 24.

27. GDM, M.G. 4180, file 8, Charles Ferdinand Martin, "Miss Gertrude Mudge, An Appreciation," in Medical Undergraduate Society, McGill University, Medical Ball in Honour of Miss Gertrude D. Mudge, Montreal, 20 Mar 1953. 28. MUA, RG 38, Container 3, file 426, Charles Ferdinand Martin to Dr. Willard Cole Rappleye.

29. GDM, M.G. 4180, file 3, passim.

30. Ibid., file 1, Allan J. Fleming to the author, 11 Jan 1966. 31. Ibid., Charles Ferdinand Martin to the author, 3 Aug 1964.

32. Ibid., Reginald E.L. Watson to the author, 5 Jan 1966. 33. Ibid., file 4, Mark R. Marshall to G. Earle Wight, 30 Jun 1953.

34. Ibid., file 1, Mrs. Hill H. Cheney to the author, 16 Aug 1964 and C.P. Martin to the author, 3 Aug 1964.

35. MUA, RG 7, Container 103, file 383, "Presentation of Miss Gertrude D. Mudge," 25 May 1955.

36. GDM, M.G. 4180, file 1, Mrs. Hill H. Cheney to the author, 16 Aug 1964; Donald Fleming, M.D., to the author, 24 Aug 1964; Walter de M. Scriver, M.D., to the author, 31 Jul 1964.

37. Ibid., Honor M. Kidd to the author, 10 Sep 1964.

38. Ibid., file 2, June B. Everett to the author, 16 Aug 1993. 39. Ibid.

40. Ibid., file 1, Charles H. Borsman to the author, $21 \mathrm{Apr}$ 1965; MUA, RG 38, Container 76, file 1074, Walter de M. Scriver to Alumnus, [May or Jun 1958].

41. Hilda Meehan, "McGill's 'Mother Confessor' Will Be Missed after 38 Years," The Gazette (Montreal), 24 Jul 1953, p. 10 .

42. GDM, M.G. 4180, file 8, Dorothy Gale, "Miss Mudge of Montreal Comes Here the Long Way," in unidentified Honolulu newspaper [1954].

43. T.H. Matthews, "Stars of the Second Magnitude-but Stars," The McGill News, 31 (Summer 1950): 81.

44. "Returning '24 Graduates Find McGill 'Bigger and Better', "The Montreal Daily Star, 22 Oct 1949, p. 3.

45. "Record Crowd at Annual Med. Ball," The Montreal Star, 21 Mar 1953, p. 11 and 23 March 1953, p. 13. 
46. See encomium entitled "Our Miss Mudge" in McGill Medical Journal, 22 (Apr 1953): [59]-60.

47. The Gertrude Mudge Fund Committee consisted of G. Earle Wight (med. '25), S.J. Martin (Med '28), J.F. Meakins (Med. '36) and G.E. Craig (med. '43).

48. GDM, M.G. 4180, file 4, Lew A. Hochberg to G. Earle Wight, n.d. [1953].

49. Ibid., J. Conrad Gemeroy to G. Earle Wight, 20 July 1953.

50. lbid., Richard B. Jamieson to G. Earle Wight, 2 July 1953.

51. "Doctors Honor Miss G. Mudge," The Montreal Star and Herald, 23 Dec 1953, p. 8; "12,320-Mile Trip Honors Promise," The Montreal Star, 11 Nov 1954, p. 3.

The author donated the quaich bowl to the Faculty of Medicine in 1993. It is now on permanent display in the dean's office. The bowl sits on a wooden base with a plaque which reads:

Miss Mudge's contributions to the Faculty of Medicine were extraordinary and encompassed areas of activities now requiring a group of individuals. This display is in honour of all the administrative staff members who support the many functions of this faculty.

Behind and above the bowl stands a framed, colored portrait photograph of Miss Mudge. The whole is encased in an acrylic box.

52. Tom Gilliland, "Retired University Secretary Visiting Many of Graduates, "Chattanooga News-Free Press, 24 Mar 1954, p. 7.

53. "12,320-Mile Trip Honors Promise," The Montreal Star, 11 Nov 1954, p. 3.

54. GDM, M.G. 4180, file 8, "Secretary to Visit 1,000 McGill Grads," The Montreal Star, 2 Mar 1954, p. 3; Tom Gilliland, "Retired University Secretary Visiting Many of Graduates," Chattanooga News-Free Press, 24 Mar 1954, p. 7; Dorothy Gale, "Miss Mudge of Montreal Comes Here the Long Way," in unidentified Honolulu newspaper [1954]; Miss Mudge Visits the Richerts," in unidentified Honolulu newspaper [1954]; Dee Lavoie, "Long Visiting List for Quebec Woman," Daily Colonist (Victoria, B.C.), 11 Aug 1954, p. 11; "McGill Doctors Honor Visitor," Daily Colonist (Victoria, B.C.), 11 Aug 1954, p. 11; Mary McAlpine, "Cupid Hinders Women Doctors," The Vancouver Sun, 18 Aug 1954, p. 24; "12,320-Mile Trip Honors Promise," The Montreal Star, 11 Nov 1954, p. 3; "What the Martlet Hears," The McGill News, 36 (Summer 1955): 7.

55. Donald H. Fleming, "In Memoriam: Miss Gertrude D. Mudge," McGill Medical Journal, 27 (Feb 1958): 2. This memorial is recorded in the Minutes of the Faculty of Medicine.

56. C. Turnbull, Medical Library, McGill University, to the author, 25 Mar 1976.

57. Mary McAlpine, "Cupid Hinders Women Doctors," The
Vancouver Sun, 18 Aug 1954, p. 24.

58. Ibid.

59. Even women physicians of the time were of the opinion that a professional women's identity was to be found first and foremost in her success as a wife and mother. See Hulda E. Thelander and Helen B. Weyrauch, "Women in Medicine," Journal of the American Medical Association, 148 (16 Feb 1952): 531-535.

60. MUA, RG 7, Container 103, file 383, F. Cyril James to Gertrude Mudge, 23 Feb 1955, MUA, RG 2, Container 170, file 5911, Gertrude Mudge to F. Cyril James, 26 Feb 1955. 61. MUA, RG 7, Container 103, file 383, "Presentation of Miss Gertrude D. Mudge for the Honorary Degree of Master of Arts..."

62. The Montreal Star, 25 May 1955, p. 8, col. 2.

63. "Miss Gertrude Mudge," The Montreal Star and Herald, 22 Jan 1958, p. 32.

64. The Gertrude Mudge Memorial Student Aid Fund Committee was co-chaired by Dr. Walter de M. Scriver (Med '21) and Dr. G. Earle Wight (Med '25), both of Montreal, and Dr. Douglas MacKinnon (Med '27) of Los Angeles.

When the fund closed its books on 30 June 1960, the committee had collected over $\$ 32,000$ which, at that time, made it "by far the largest student loan fund in the Medical Faculty-and by far the most generous." See MUA, RG 76, Container 65, files 1071 and 1074. As of April 1993, the fund had a value of $\$ 48,468$.

According to the terms set out in the circular letters soliciting funds, the money was to be used for student aid at the discretion of the Faculty of Medicine. At its meeting of 16 September 1958 , the faculty decided that it would like to open a rotating loan fund whereby the loans would be interest free for the first three years and then bear interest at 2 per cent per year. The maximum amount to be lent to any student is the amount of the annual fees. See MUA, RG 4, Container 246, file 3934, Lloyd G. Stevenson to J.H. Holton, 22 Sep 1958; also A.B.C. Schlichter to Mrs. Derouchie, 7 Oct 1958; and J.H. Holton to D.C. Bain and R. Kuranoff, 5 Jun 1959. 65. MUA, McGill University, Annual Report, 1924-1925, p. 119. Regrettably the memorial tablet to Miss Brand no longer exists, and nobody on campus today has any recollection of it. According to Dr. M.F. Lalli, superintendent of the Strathcona Anatomy and Dentistry Building, the tablet was never a part of the inventory of the building's collection of art works and memorials.

66. GDM, M.G. 4180, file 1, Walter de M. Scriver to the author, $31 \mathrm{Jul} 1964$.

67. Ibid., file 8, Charles Ferdinand Martin, "Miss Gertrude Mudge, an Appreciation," in Medical Undergraduate Society, McGill University, Medical Ball in Honor of Miss Gertrude D. Mudge, Montreal, 20 Mar 1953.

68. "Miss Gertrude Mudge" (Editorial), The Montreal Star and Herald, 23 Jan 1958, p. 10.

69. GDM, M.G. 4180, file 4, Milton Greenberg to G. Earle Wight, 3 Jul 1953. 